\title{
Dislocation of Sialic Acid on Erythrocytes Membrane by Anesthetics and its Blocking by SH-reagents, Colchicine or Cytochalasin B
}

\author{
Chikako Sato, Kiyohide Kojima*, Kimiko Nishizawa and Kazuya Sato \\ Laboratory of Experimental Radiology, Aichi Cancer Center Research Institute, \\ Chikusa-ku, Nagoya 464, Japan, and *Laboratory of Oncological Pathology, \\ Nara Medical University
}

\begin{abstract}
The cell electrophoretic mobility of rat erythrocytes decreased by treatment with thiopental or droperidol (intravenous anesthetics) at clinical concentrations. The amount of sialic acid, the main determinant of electrophoretic mobility, was not changed by the anesthetics. By using phosphate buffers of different ionic strengths, which determines the effective thickness of the ionic layer for electrophoretic mobility, translocation of sialic acid from the most peripheral zone to a deeper zone was suggested. When mobility recovered by washing out of the drugs followed by subsequent incubation, sialic acid was restored to the peripheral zone. The decrease in mobility was inhibited by sulfhydryl-blocking agents and disulfide-bridging agent. Cytochalasin B and colchicine completely blocked the mobility reduction when used single, but not when used simultaneously. These results suggest conformational changes of membrane sialoprotein by anesthetics involving sulfhydryls and cytochalasin B- and colchicine-sensitive proteins.
\end{abstract}

The primary action of anesthetics has been generally assumed to be on the membrane (24). However, the mechanism of the action of anesthetics is still under extensive investigation and debate (24). Electrical stabilization of the membrane (28), expansion (23), membrane fluidization (13), membrane disordering $(15,16,25)$, changes in the activity of enzymes (24), depolimerization of microtubules (1), and displacement of calcium by local anesthetics (3) have been reported. Conformational changes of the membrane protein $(6,27)$ and perturbation of the lipid bilayer $(14)$ are the main hypotheses to explain the anesthetic action causing these phenomena. Substantial data are required on the membrane structure, the interaction between proteins and lipids, and their regulation mechanism in normal or anesthetized cells, before anesthetic action can be fully explained.

We applied cell electrophoresis (7) to investigate the effect of anesthetics on membrane structure (23). This is a sensitive method to detect the distribution of negatively charged substances without damaging the cell. We have developed a combination method using specific enzymes and electrophoresis at different ionic strengths to detect the translocation of acidic sugars after $\mathrm{x}$-irrariation $(20,21)$. This method revealed a conformational change in sialoproteins caused by intravenous anesthetics.

\section{MATERIALS AND METHODS}

Erythrocytes from Wistar King A rats were taken by heart puncture without using an 
anticoagulant before each experiment, and placed in $\mathrm{Ca}^{++}$-free phosphate buffered saline. After incubation with various concentrations of thiopental or droperidol in Dulbecco's phosphate buffered saline with $\mathrm{Ca}^{++}$and $\mathrm{Mg}^{++}$for $30 \mathrm{~min}$ at $37^{\circ} \mathrm{C}$, the erythrocytes were washed twice with the buffer solution and used for electrophoresis.

The electrophoretic mobility of individual cells was measured at $25 \pm 0.5^{\circ} \mathrm{C}$ with a cytopherometer (Zeiss) (7). Each cell was allowed to move $16 \mu \mathrm{m}$ alternately in both directions following the reversal of current in $67 \mathrm{mM}$ phosphate buffer supplemented with $5.4 \%$ glucose ( $\mathrm{pH} 7.3$, ionic strength 0.167 ). Mobility was determined from three separate experiments on $30-100$ cells for each point and calculated in $\mu \mathrm{m} \cdot \mathrm{sec}^{-1} \cdot \mathrm{V}^{-1} \cdot \mathrm{cm}$. To measure the mobility at different ionic strengths of the solution, phosphate buffer $(67 \mathrm{mM}, \mathrm{pH} 7.3$, ionic strength 0.167 ) was diluted with water, then supplemented with $5.4 \%$ glucose to maintain isotonicity. The conductance $(\mu \nu / \mathrm{cm})$ of each buffer solution was measured with a conductometer, and resistance $(\Omega \mathrm{cm})$ was determined. Mobility was calculated with the following equation.

$$
\text { Mobility }=\frac{\text { distance of traverse }(\mu \mathrm{m}) \times 0.9828 \times \text { height }(\mathrm{cm}) \times \text { depth }(\mathrm{cm})}{\text { time }(\mathrm{sec}) \times \text { electric current }(\mathrm{A}) \times \text { resistance }(\Omega \mathrm{cm})}
$$

The correction factor 0.9828 is for the position of the first stationary plane without liquid circulation due to electroendosmosis in the measuring vessel. Distance and current were chosen to give about $10 \mathrm{sec}$ of traverse for each cell.

To modify the effect of anesthetics, erythrocytes were preincubated with $1 \mu \mathrm{g} / \mathrm{ml}$ cytochalasin $\mathrm{B}, 0.1 \mu \mathrm{g} / \mathrm{ml}$ colchicine, or different concentrations of N-ethyl-maleimide, p-chloromercuri-benzoic acid or fluoromercuric acetate in phosphate buffered saline for 15 minutes at $37^{\circ} \mathrm{C}$ or $4^{\circ} \mathrm{C}$. They were then washed with PBS, after which thiopental or droperidol was added to the final concentration of $100 \mu \mathrm{g} / \mathrm{ml}$ or $10 \mu \mathrm{g} / \mathrm{ml}$ for the next incubation for 30 minutes at $37^{\circ} \mathrm{C}$. In the other groups, cytochalasin $\mathrm{B}$ and/or colchicine and the anesthetics were added simultaneously.

The amounts of sialic acid and protein were determined by the methods of Aminoff (2) and Lowry (11), respectively. Enzymatic treatment of cells was performed as described in a previous paper (18). No hemolysis was observed in these experiments.

\section{RESULTS}

Dose-effect relationship. Fig. 1 shows the relationship between the concentration of thiopental or droperidol and the mobility of erythrocytes after incubation for 30 minutes at $37^{\circ} \mathrm{C}$. The mobility reducing effect changed gradually when the concentration of thiopental increased from 0.5 to $100 \mu \mathrm{g} / \mathrm{ml}$. For droperidol the effect changed markedly from 0.3 to $1 \mu \mathrm{g} / \mathrm{ml}$. At clinical concentrations $(5 \mu \mathrm{g} / \mathrm{ml}$ thiopental and $1 \mu \mathrm{g} / \mathrm{ml}$ droperidol), mobility reduction was about $70 \%$ of the maximum change induced by the highest concentration of anesthetics examined $(100 \mu \mathrm{g} / \mathrm{ml}$ thiopental and $20 \mu \mathrm{g} / \mathrm{ml}$ droperidol).

Amount of sialic acid. Removal of sialic acid by incubation of whole erythrocytes with neuraminidase (from Vibrio cholerae, General Biochemicals Inc.) 20 units/ml in Hanks' balanced salt solution ( $\mathrm{pH} \mathrm{7.4)} \mathrm{for} 30 \mathrm{~min}$ at $37^{\circ} \mathrm{C}$ resulted in a mobility reduction of $60 \%$. Treatments with hyaluronidase $(10$ units $/ \mathrm{ml})$ or chondroitinase ABC (1 unit $/ \mathrm{ml})$ had no effects on the mobility. This means that sialic acid is the predominant acidic sugar responsible for the mobility. The amount of sialic acid was determined on erythrocyte ghosts prepared by hypotonic hemolysis after treatment with anesthetics for one hour. As indicated in table 1, the content of sialic acid per 


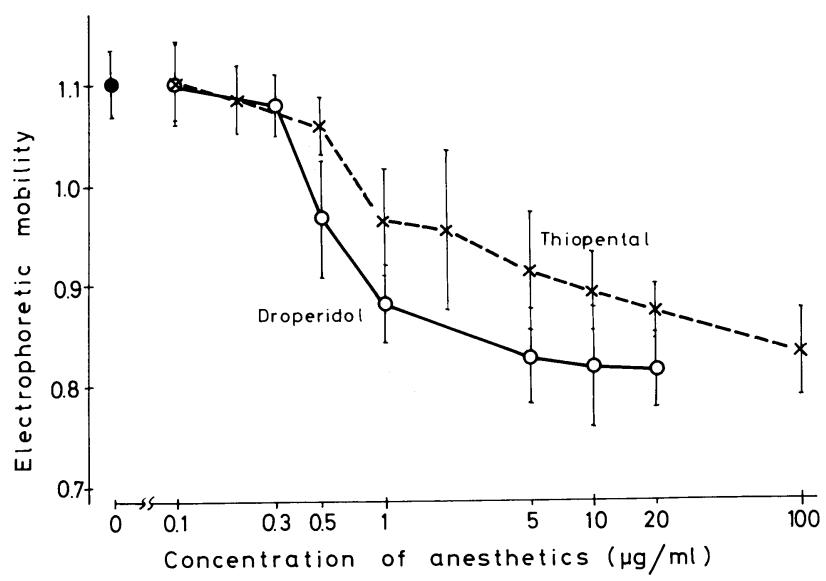

Fig. 1. Relationship between the concentration of anesthetics (Thiopental - - $\times---$, Droperidol - - ) and cell electrophoretic mobility after treatment for 30 minutes. The vertical line represents standard deviation of the mean.

TABLE 1. AMOUNT OF SIALIC ACID IN ERYTHROCYTE GHOSTS

Treatment

\section{No treatment}

Thiopental $100 \mu \mathrm{g} / \mathrm{ml} 1 \mathrm{~h}$

Droperidol $10 \mu \mathrm{g} / \mathrm{ml} 1 \mathrm{~h}$
Sialic acid (n moles/mg protein)

$84.6+5.2$

$87.1 \pm 6.1$

$82.9 \pm 4.6$

Results are the averages of four determinations \pm SD.

Fig. 2. Relationship between the ionic strength of the measuring phosphate buffer and the electrophoretic mobility of control cells (-O-); anesthetized cells with thiopental $(100 \mu \mathrm{g} / \mathrm{ml})$ for 30 min (-๑); and recovered cells (thiopental 100 $\mu \mathrm{g} / \mathrm{ml} 30 \mathrm{~min} \rightarrow$ wash $\rightarrow$ incubation in culture medium for 4 hour $-\times-)$. The vertical line represents standard deviation of the mean.

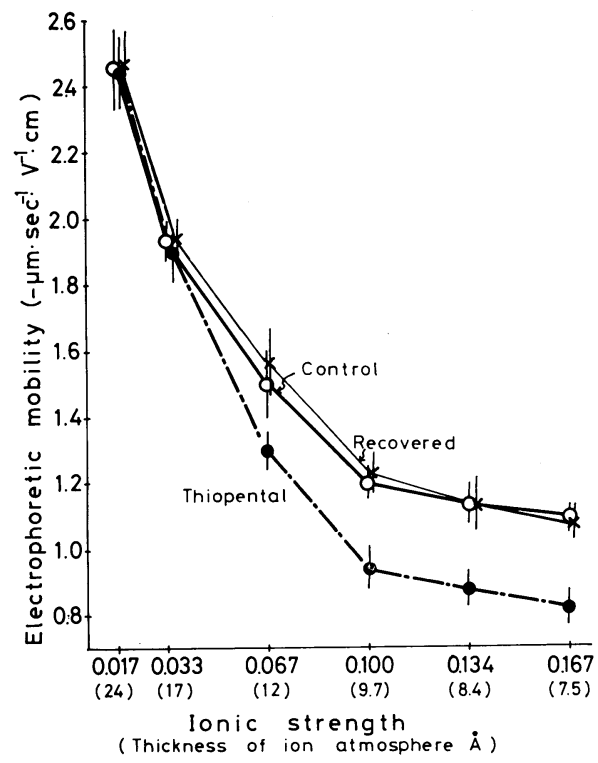


milligram of protein in the membrane remained constant after the drug treatment, and was unrelated to the mobility decrease.

Effect of ionic strength on mobility. Figure 2 shows the relationship between the ionic strength of the phosphate buffer used for the measurement and the electrophoretic mobility. Each buffer contained $5.4 \%$ glucose to maintain isotonicity. With decreasing ionic strength mobility increased. The difference in mobility between the anesthetized and control erythrocytes was maximum at ionic strengths above 0.100 . The mobility at ionic strengths lower than 0.033 was the same as in the anesthetized and control cells. With decreasing ionic strength, the thickness of the ion atmosphere increases. According to Debye-Huckel's equation, the thickness of the ion atmosphere $=3.06 \times(\text { ionic strength })^{-\frac{1}{2}} \dot{\mathrm{A}}$. The values are $7.5,9.7$ and $17 \dot{\mathrm{A}}$ for the ionic strengths of $0.167,0.100$ and 0.033 , respectively. If we use the thickness of the ion atmosphere as an approximate estimation of the effective electrokinetic plane of shear, then dislocation of a negatively charged substance from the peripheral zone of 0-7.5 $\dot{\mathrm{A}}$ to the deeper zone of $9.7-17 \dot{\mathrm{A}}$ is suggested. When mobility was recovered after thiopental had been washed out and the cells had been incubated for 4 hours, the mobility changed with ionic strength as in the non-treated cells.

Agents modifying mobility change. Pretreatment of cells with sulfhydryl-blocking agents (N-ethyl-maleimide and p-chloromercuri-benzoic acid) or a disulfide-bridging agent (fluoromercuric acetate) for 15 min blocked the mobility reduction caused by anesthetics depending on the concentration. Fig. 3 shows the relationship between the concentration of the sulf hydryl-modifying agents and the electrophoretic mobility measured after $30 \mathrm{~min}$ of incubation with $100 \mu \mathrm{g} / \mathrm{ml}$ thiopental or $10 \mu \mathrm{g} / \mathrm{ml}$ droperidol at $37^{\circ} \mathrm{C}$. The inhibition ratio of the decrease in electrophoretic mobility was proportional to the log of the concentration (or presumably the log of the ratio of the blocked sulf hydryls).

Table 2 indicates the effect of the depolymerizing agents of contratile proteins on the mobility reduction by thiopental $(100 \mu \mathrm{g} / \mathrm{ml})$. Preincubation with cytochalasin B and colchicine for $15 \mathrm{~min}$ at $37^{\circ} \mathrm{C}$ completely blocked the mobility reduction when each agents was used singly, but not when used simultaneously. The blocking effect was much reduced when the preincubation with these agents was done at $4^{\circ} \mathrm{C}$. The

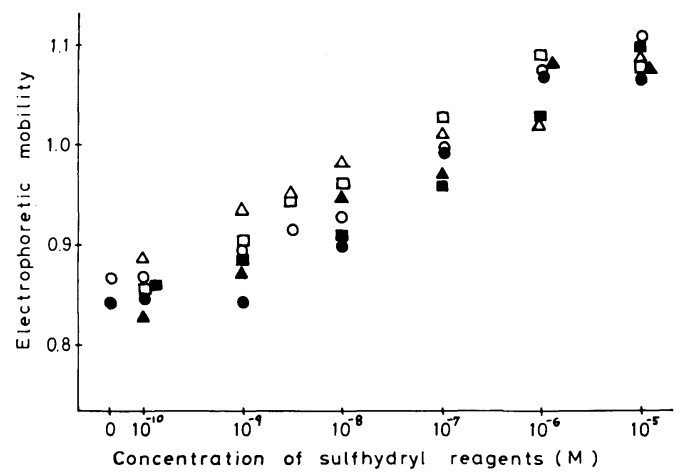

Fig. 3. Relationship between electrophoretic mobility $\left(-\mu \mathrm{m} \cdot \mathrm{sec}^{-1} \cdot \mathrm{V} \cdot{ }^{-1} \cdot \mathrm{cm}\right)$ and the concentration of N-ethylmaleimide $(\bigcirc, \bullet)$, p-chloro-mercuri-bezoic acid $(\triangle, \Delta)$, and Fluoromercuric acetate $(\square, \boldsymbol{\square})$. Open symbols are for thiopental $100 \mu \mathrm{g} / \mathrm{ml}$ and closed symbols for droperidol $10 \mu \mathrm{g} / \mathrm{ml}$. Preincubation with sulfhydryl reagents for $15 \mathrm{~min}$ and subsequent incubation with anesthetics for $30 \mathrm{~min}$. 
TABLE 2. MODIFYING EFFECT OF CYTOCHALASIN B AND COLCHICINE ON MOBILITY CHANGE BY THIOPENTAL

\begin{tabular}{|c|c|}
\hline Treatment & $\begin{array}{l}\text { Electrophoretic mobility } \\
\left(\mu \mathrm{m} \cdot \mathrm{sec}^{-1} \cdot \mathrm{V}^{-1} \cdot \mathrm{cm}\right)\end{array}$ \\
\hline No treatment & $-1.100 \pm 0.042$ \\
\hline Thipental $30 \min 37^{\circ} \mathrm{C}$ & $-0.841 \pm 0.049$ \\
\hline Cyt. B $37^{\circ} \mathrm{C} 15 \mathrm{~min} \rightarrow$ wash $\rightarrow$ Thiopental & $-1.050 \pm 0.059$ \\
\hline Cyt. B $4^{\circ} \mathrm{C} 15 \mathrm{~min} \rightarrow$ wash $\rightarrow$ Thiopental & $-0.919 \pm 0.074$ \\
\hline Cyt. B+Thiopental $30 \mathrm{~min}$ & $-0.774 \pm 0.050$ \\
\hline Col. $37^{\circ} \mathrm{C} 15 \mathrm{~min} \rightarrow$ wash $\rightarrow$ Thiopental & $-1.052 \pm 0.061$ \\
\hline Col. $4^{\circ} \mathrm{C} 15 \mathrm{~min} \rightarrow$ wash $\rightarrow$ Thiopental & $-0.894 \pm 0.054$ \\
\hline Col.+Thiopental $30 \mathrm{~min}$ & $-0.798 \pm 0.059$ \\
\hline Cyt. $\mathrm{B}+$ Col. $37^{\circ} \mathrm{C} 15 \mathrm{~min} \rightarrow$ wath $\rightarrow$ Thiopental & $-0.891 \pm 0.048$ \\
\hline Cyt. B + Col. + Thiopental $30 \mathrm{~min}$ & $-0.744 \pm 0.057$ \\
\hline Cyt. B $37^{\circ} \mathrm{C} 1 \mathrm{~h}$ & $-1.079 \pm 0.039$ \\
\hline Col. $37^{\circ} \mathrm{C} 1 \mathrm{~h}$ & $-1.067 \pm 0.045$ \\
\hline Cyt. B+Col. $37^{\circ} \mathrm{C} 1 \mathrm{~h}$ & $\begin{array}{c}-1.054 \pm 0.081 \\
\text { (mean } \pm \text { s.d.) }\end{array}$ \\
\hline
\end{tabular}

Thiopental $100 \mu \mathrm{g} / \mathrm{ml}$. Cytochalasin B (Cyt. B) $1 \mu \mathrm{g} / \mathrm{m}$, Colchicine (Col.) $0.1 \mu \mathrm{g} / \mathrm{ml}$ in Dulbecco's phosphate buffered saline. Treatment with thiopental was done at $37^{\circ} \mathrm{C}$.

presence of these drugs during treatment with anesthetics enhanced mobility reduction. Incubation with $1 \mu \mathrm{g} / \mathrm{ml}$ cytochalasin B and/or $0.1 \mu \mathrm{g} / \mathrm{ml}$ colchicine per se at $37^{\circ} \mathrm{C}$ for $1 \mathrm{hr}$ had no effect on the electrophoretic mobility. However, higher concentrations and/or longer incubation resulted in a reduction mobility.

\section{DISCUSSION}

In recent years, anesthetics have been used not only in investigation of the mechanism of anesthetic action but also as stimulants to determine the regulation of membrane structure and function. Anesthetics induce the inhibition of cell growth (10), the depolymerization of microtubules $(1,8)$, and enhance agglutinability by concanavalin A (17).

The results of this experiment with cell electrophoresis add evidence of membrane disorder due to anesthetics. Detection of mobility reduction only with a buffer solution of high ionic strengths without change in the amount of sialic acid suggests a conformational change in the sialoproteins which causes a translocation of sialic aicd from the peripheral zone to a deeper one. Although the effective thickness of the ionic layer increases with decreasing ionic strength $(4,9,12)$, it is difficult to determine the exact depth of the electrokinetic plane of shear, because the cell surface is not smooth, and its architecture may change with ionic strength. Assuming a free penetration of ions in the hydrophilic layer where the sialic acid exists, we used the thickness of the ion atmosphere as an approximate estimation of the effective ion layer for the zeta potential.

Inhibition of the reduction of mobility by anesthetics was proportional to the logarithm of the concentration of sulf hydryl-blocking or disulfide-bridging agents. This suggests that the sulfhydryls of the membrane proteins are involved in the facility of movement of sialic acid (18). The site of the critical protein could not be determined in this experiment. Pretreatment with colchicine or cytochalasin $\mathrm{B}$ at $37^{\circ} \mathrm{C}$ (not at $4^{\circ} \mathrm{C}$ ) 
completely blocked the mobility reduction by thiopental, but simultaneous treatment with thiopental somewhat enhanced this reduction. This implies that the mobility reduction by anesthetics depends on the condition of proteins sensitive to cytochalasin $\mathrm{B}$ and colchicine. That there was no effects caused by pretreatment with both cytochalasin B and colchicine is an apparent but reproducible paradox. Impairment of membrane peripheral proteins sensitive to colchicine and cytochalasin B by local anesthetics has been suggested (16), and the mechanism of the regulation of the lection receptor mobility by $\mathrm{Ca}^{2+}$ and peripheral proteins with different roles has been envisaged $(5,17,26)$. The results of our experiment suggest that not only the lateral movement of lection receptros but also the conformation of sialoproteins are regulated by colchicine and cytochalasin- sensitive proteins, and are changed by anesthetics.

Acknowledgment. This work was supported in part by a Grant-in-Aid for Scientific Research and Cancer Research from the Ministry of Education and the Ministry of Health and Welfare, Japan.

\section{REFERENCES}

1. Allison, A. C. and J. F. NunN. Effects of general anaesthetics on microtubules. A possible mechanism of anaesthesia. Lancet. 2, 1326-1329, 1968

2. Aminoff, D. Methods for the quantitative estimation of $\mathrm{N}$-acetylneuraminic acid and their application to hydrolysates of sialomucoids. Biochem. J. 81, 384-392, 1961

3. Blaustein, M. P. and D. Goldman. Action of anionic and cationic nerve-blocking agents: Experiment and interpretation. Science 153, 429-432, 1966

4. Brinton, C.C.Jr. and M.A. LAuffer. Electrophoresis Vol. I. Theory, method and applications, Academic Press, New York, pp. 427-491, 1969

5. Edelman, G.M., I. Yahara and J.L. WANG. Receptor mobility and receptor-cytoplasmic interactions in lymphocytes. Proc. Natl. Acad. Sci. 70, 1442-1446, 1973

6. Eyring, E., J.W. Woodbury and J.S. D'Arrigo. A molecular mechanism of general anesthesia. Anesthesiol. 38, 415-424, 1973

7. Fuhrmann, G.F. and G. Ruhenstroth-Bauer. Cell electrophoresis, Churchill, London, pp. 22-35, 1965

8. HaschKe, P.H., M.R. Byers and B.R. Fink. Effects of lidocaine on rabbit brain microtubular protein. J. Neurochem. 22, 837-843, 1974

9. Heard, D.H. and G.V.F. Seaman. The influence of $\mathrm{pH}$ and ionic strength on the electrokinetic stability of the human erythrocyte membrane. J. Gen. Physiol. 43, 635-654, 1960

10. Hinkley, R.E. and A.G. Telser. The effects of halothane on microfilamentous system in cultured neuroblastoma cells. Progress in Anesthesiology, Vol. I, Raven Press, New York, p. 13, 1975

11. Lowry, O.H., N.J. Rosebrough, A.L. Farr and R.J. Randall. Protein measurement with the Folin phenol reagent. J. Biol. Chem. 193, 265-275, 1951.

12. MAdDY, A.H. The chemical organization of plasma membrane of animal cells. Int. Rev.,Cytol. 20, 1-65, 1966

13. Metcalfe, J.C. and A.S.V. Burgen. Relaxation of anaesthetics in the presence of cyto-membranes. Nature 220, 587-588, 1968

14. Papahadjopoulos, D. Studies on the mechanism of action of local anesthetics with phospholipid model membranes. Biochim. Biophys. Acta 265, 169-186, 1972

15. Paterson, S.J., K.W. Butler, P. Huang, J. Labelle, I.C.P. Smith and I.C.P. Schneider. The effects of alcohols on lipid bilayers: a spin label study., Biochim. Biophys. Acta 266, 597-602, 1972

16. Poste, G., D. Papahadhopoulos, K. Jacobson and W.J. Vall. Effects of local anesthetics on membrane properties II. Enhancement of the susceptibility of mammalian cells to agglutination by plant lectins. Biochim. Biophys. Acta 394, 520-539, 1975

17. Poste, G., D. Papahadhopoulos, K. Jacobson and W.J. Vall. Local anaesthetics increase 
susceptibility of untransformed cells to agglutination by concanavalin A. Nature 253, 552-554, 1975

18. Sato, C. and K. KoJima. Changes in electrophoretic mobiltiy of cultured cells after $\mathrm{x}$-irradiation and their modification by SH-blocking agents and hemagglutinin. Radiat. Res. 60, 506-515, 1974

19. Sato, C., K. Kojima, K. Nishizawa, S. Shimizu and M. Inoue. Small amount of concanavalin A modifies radiation-induced alteration in cell surface charge depending on its binding condition. Bioch. Biophys. Acta 448, 379-387, 1976

20. Sato, C., K. Kojima and K. Nishizawa. Target of X-irradiation and dislocation of sialic acid in decrease of cell surface charge of erythrocytes. Radiat. Res. 69, 367-374, 1977

21. Sato, C., K. Kojima and K. Nishizawa. Translocation of hyaluronic acid in cell surface of cultured mammalian cells after x-irradiation and its recovery by added adenosine triphosphate. Biochim. Biophys. Acta 470, 446-452, 1977

22. Sato, K., K. Kojima and C. SAto. Decrease and recovery in cell surface charge induced by anesthetics. Tohoku J. exp. Med. 123, 185-190, 1977

23. Seeman, P., W. O. Kwant, T. Sauks and W. Argent. Membrane expansion of intact erythrocytes by anesthetics. Biochim. Biophys. Acta 183, 490-498, 1969

24 Seeman, P. The membrane actions of anesthetics and tranquilizers. Pharmacological Reviews 24, 583-655, 1972

25. Spero, L. and S. Roth. Fluorescent hydrophobic probe study of the interaction between local anesthetics and red cell ghosts. Fed. Proc. 29, pp. 474, 1970

26. Ukena, T.E., J.Z. Borysenko, M.J. Karnovsky and R.D. Berlin. Effects of colchicine, cytochalasin B. and 2-deoxyglucose on the topographical organization of surface-bound concanavalin A in normal and transformed fibroblasts. J. Cell Biol. 61, 70-82, 1974

27. I. Ueda, H. Kamaya and H. Eyring. Molecular mechanism of inhibition of firefly luminescence by local anesthetics. Proc. Nat. Acad. Sci. 73, 481-485, 1976

28. Weidman, S. Effects of calcium ions and local anesthetics on Purkinje fibers. J. Physiol. 129, $568-582,1955$

(Received for publication, May 29, 1978) 